\title{
Synthesis and herbicidal activities of aryloxyacetic acid derivatives as HPPD inhibitors
}

\author{
Man-Man Wang, Hao Huang, Lei Shu, Jian-Min Liu, Jian-Qiu Zhang, Yi-Le Yan \\ and Da-Yong Zhang*
}

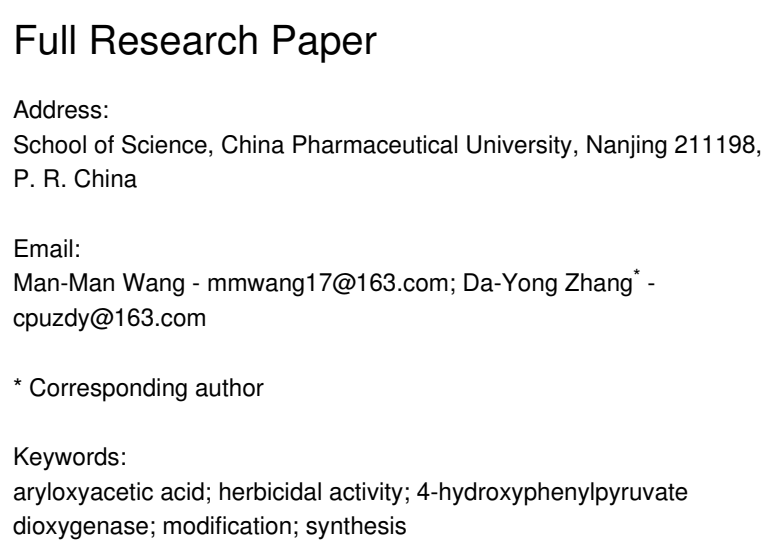

Beilstein J. Org. Chem. 2020, 16, 233-247.

doi:10.3762/bjoc. 16.25

Received: 27 November 2019

Accepted: 07 February 2020

Published: 19 February 2020

Associate Editor: J. S. Dickschat

(c) 2020 Wang et al.; licensee Beilstein-Institut. License and terms: see end of document.

\begin{abstract}
A series of aryloxyacetic acid derivatives were designed and synthesized as 4-hydoxyphenylpyruvate dioxygenase (HPPD) inhibitors. Preliminary bioassay results reveal that these derivatives are promising Arabidopsis thaliana HPPD (AtHPPD) inhibitors, in particular compounds I12 $\left(K_{\mathrm{i}}=0.011 \mu \mathrm{M}\right)$ and $\mathbf{I 2 3}\left(K_{\mathrm{i}}=0.012 \mu \mathrm{M}\right)$, which exhibit similar activities to that of mesotrione, a commercial HPPD herbicide $\left(K_{\mathrm{i}}=0.013 \mu \mathrm{M}\right)$. Furthermore, the newly synthesized compounds show significant greenhouse herbicidal activities against tested weeds at dosages of $150 \mathrm{~g}$ ai/ha. In particular, II4 exhibited high herbicidal activity for pre-emergence treatment that was slightly better than that of mesotrione. In addition, compound II4 was safe for weed control in maize fields at a rate of $150 \mathrm{~g}$ ai/ha, and was identified as the most potent candidate for a novel HPPD inhibitor herbicide. The compounds described herein may provide useful guidance for the design of new HPPD inhibiting herbicides and their modification.
\end{abstract}

\section{Introduction}

4-Hydroxyphenylpyruvate dioxygenase (EC 1.13.11.27, HPPD), which belongs to the family of non-heme Fe $\mathrm{II}_{\text {-contain- }}$ ing enzymes, is a vital enzyme for tyrosine catabolism. This enzyme is found in microbes, mammals, and plants, and has different functions in different organisms [1]. In the catalytic process of HPPD, 4-hydroxyphenylpyruvic acid (HPPA) and $\mathrm{Fe}^{\mathrm{II}}$ form a chelate complex, from which the HPPA substrate is converted into homogentisic acid (HGA). The generally accepted catalytic mechanism for this process is shown in
Scheme 1 [2-6]. The HPPD amino acid sequence homologies in plants and mammals are significantly different $[7,8]$, and this difference affects the binding stability between an inhibitor and HPPD, leading to inhibitor activities that differ among various species and genera and providing a theoretical basis for the design of inhibitors that are highly selective and safe [2].

In plants, HPPD inhibitors competitively restrain HPPA from chelating to $\mathrm{Fe}^{\mathrm{II}}$. The production of plastoquinone is inhibited 


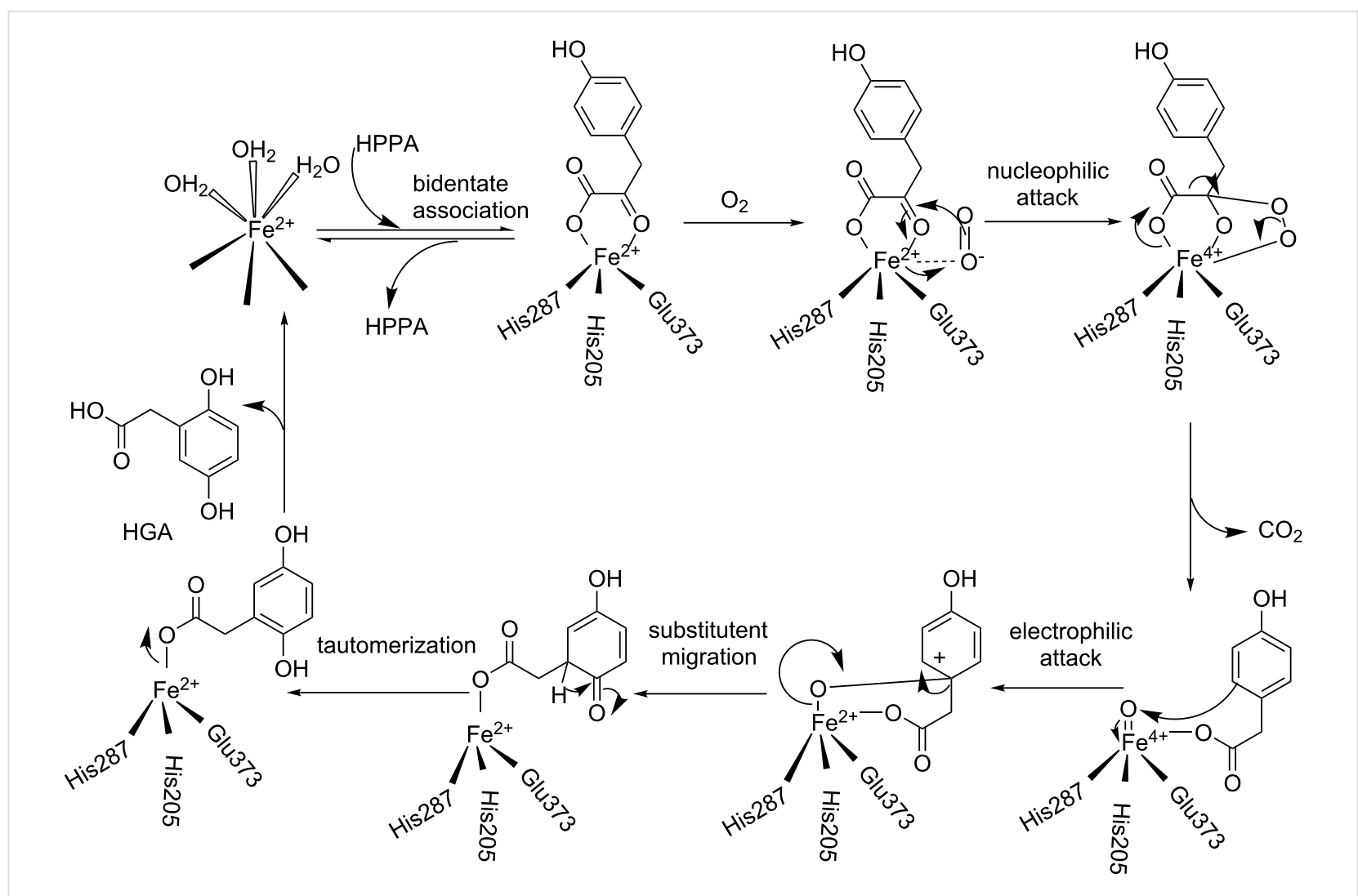

Scheme 1: The commonly recognized HPPD catalytic reaction mechanism.

and phytoene is accumulated when the transformation of HPPA to HGA is interfered with an HPPD inhibitor $[9,10]$; consequently, plants become severely damage when exposed to sunlight, ultimately resulting in bleaching symptoms followed by necrosis and death $[11,12]$. Therefore, HPPD inhibitors play important roles in the herbicide industry. In addition, HPPD inhibiting herbicides are advantageous because of their low toxicities, high efficiencies, broad-spectrum weed control, and safety toward crops and the environment [13-15]. However, the abuse of HPPD inhibitors has led to increased weed resistance and crop damage. Furthermore, the long-term applications of a single herbicide result in the resistance of the weed to the agent [14]. Therefore, exploring effective HPPD-inhibiting compounds for the control of resistant weeds is an emergent and important objective [2].

A considerable number of HPPD inhibiting herbicides have recently been commercialized and applied in the agrochemical industry. These herbicides are mainly divided into three categories: triketones, pyrazoles, and isoxazoles $[9,15,16]$. Figure 1 shows some HPPD-inhibiting herbicides, namely mesotrione, tefuryltrione, isoxaflutole, topramezone, and pyrasulfotole. Among them, mesotrione is a highly successful representative triketone HPPD herbicide. Figure 1 reveals that the HPPD in- hibiting herbicides mostly contain 1,3-dicarbonyl or analogous structures [11,15]. Arabidopsis thaliana HPPD (AtHPPD) and its inhibitors have been reported to interact in two ways: 1) through 1,3-dicarbonyl bidentate chelation with the active center metal, and 2) through favorable sandwich $\pi-\pi$ stacking interactions between aromatic rings and the Phe360, Phe403 residues of the active site. Thus, 1,3-dicarbonyl and aromatic moieties are indispensable pharmacophores for potent HPPDinhibiting compounds that interact with surrounding residues in AtHPPD [16-19].

2,4-Dichlorophenoxyacetic acid (2,4-D), which acts as a plant growth hormone, was synthesized in 1941. It is a selective preand post-emergence herbicide that has applied to several crops [17]. 2,4-D interferes with the hormone balance of the plant, which interrupts nucleic-acid and protein metabolism, and is especially effective in broadleaf weeds, such as Amaranthus retroflexus and Alfalfa. The application of 2,4-D causes excessive growth that ultimately results in plant death. Consequently, 2,4-D has become one of the world's major herbicides because low dosage is used and less investment costs are required.

Many researches in HPPD inhibitors have revealed that modifying of aromatic moieties is an effective way of producing new 
<smiles>CS(=O)(=O)c1ccc(C(=O)C2C(=O)CCCC2=O)c([N+](=O)[O-])c1</smiles>

mesotrione<smiles>CS(=O)(=O)c1ccc(C(=O)C2C(=O)CCCC2=O)c(Cl)c1COCC1CCCO1</smiles>

tefuryltrione<smiles>Cc1noc(C2CC2)c1C(=O)c1ccc(C(F)(F)F)cc1S(C)(=O)=O</smiles>

isoxaflutole<smiles>Cc1nn(C)c(O)c1C(=O)c1ccc(S(C)(=O)=O)c(C2=NOCC2)c1C</smiles>

topramezone<smiles>Cc1nn(C)c(O)c1C(=O)c1ccc(C(F)(F)F)cc1S(C)(=O)=O</smiles>

pyrasulfotole

Figure 1: Chemical structures of the commercial HPPD inhibitors.

HPPD inhibiting herbicides [20-23]. However, little effort has been directed toward modifying pyrazole derivatives and the carbon-carbon bond between 1,3-dicarbonyl and aroyl moieties. Previously, a series of 2-(aryloxyacetyl)cyclohexane1,3-diones was synthesized by Wang et al. [24]. We have been interested in inserting a carbon-oxygen bond between the triketone and aroyl moieties of HPPD inhibitors. Initially, molecular docking studies were performed on two representative compounds, namely I39 and I40 [25], in order to explore their binding modes. The result revealed the presence of two main interactions, the sandwich $\pi-\pi$ interaction and the bidentate interaction, which are similar to those of commercial mesotrione. Inspired by the above revelations, we synthesized a group of new HPPD inhibitors that contain pyrazole and triketone moieties to study their bioactivities; the design strategy is shown in Figure 2. By combining the two bioactive structures, namely the aromatic moieties of 2,4-D and the 1,3-dicarbonyl unit, we designed and synthesized a series of novel aryloxy-

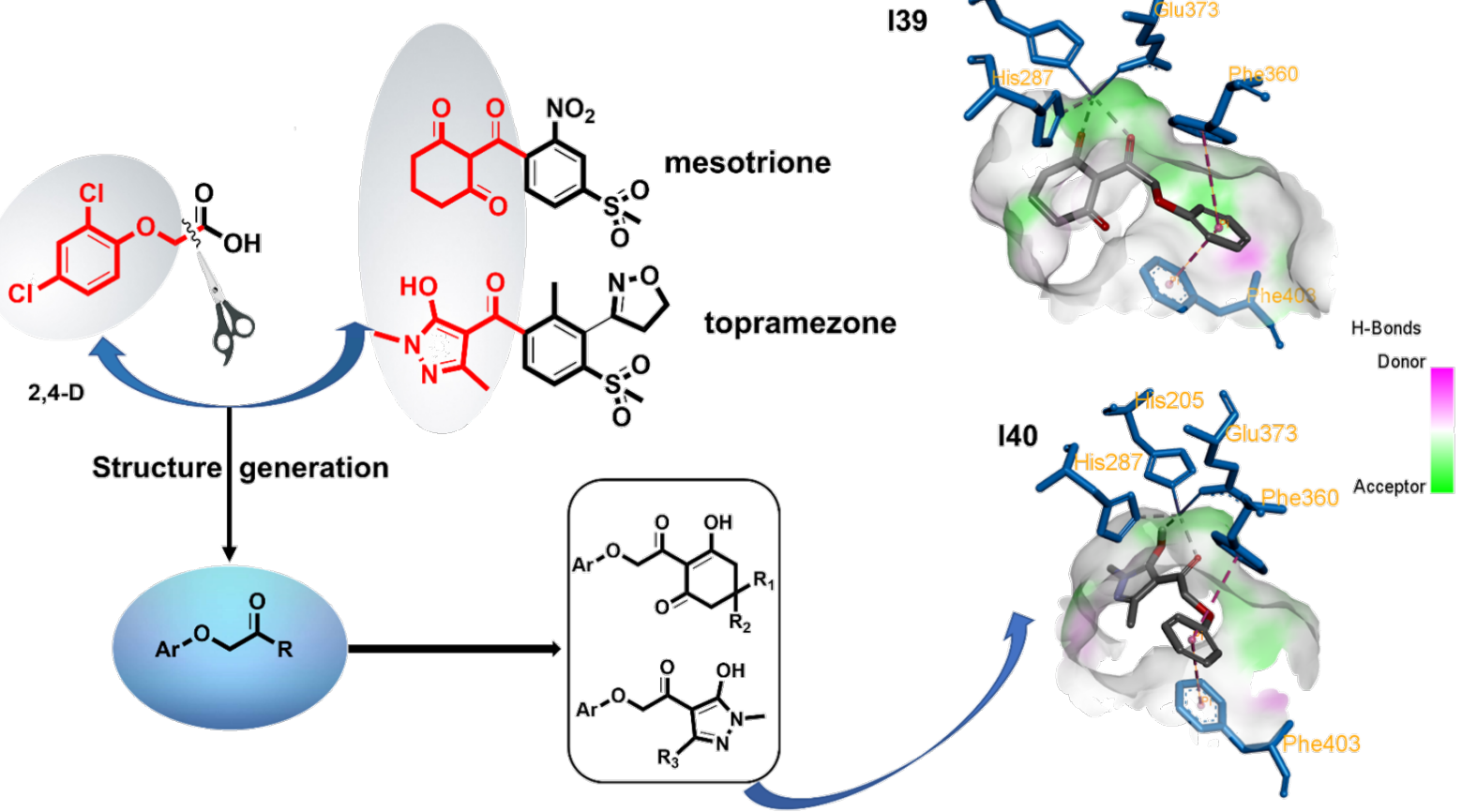

Figure 2: The design strategy of aryloxyacetic acid derivatives as HPPD inhibitors and simulate the binding modes of compound I39 and $\mathbf{1 4 0}$ in a target enzyme (AtHPPD). The key residues in the active site are shown in blue sticks, the Fe $\mathrm{e}^{\mathrm{II}}$ is shown as a dark blue sphere, and compound I39 and 140 is shown in gray sticks. 
acetic acid derivatives. In this context, these derivatives were subjected to HPPD inhibition, herbicidal activity, crop safety and structure-activity relationship (SAR) studies. As expected, many of the title compounds displayed promising inhibitory activity against Arabidopsis thaliana HPPD (AtHPPD) in vitro and excellent herbicidal activities at a rate of $150 \mathrm{~g}$ ai/ha.

\section{Results and Discussion Chemistry}

Title compounds were classified into three series (I, II and III). The preparation of the title compounds is shown in Scheme 2, Scheme 3 and Scheme 4. The synthesis of compounds I and III was depicted in Scheme 2 and Scheme 3. The commercially available starting materials reacted with methyl chloroacetate in $\mathrm{CH}_{3} \mathrm{CN}$ and anhydrous potassium carbonate $\left(\mathrm{K}_{2} \mathrm{CO}_{3}\right)$ as the base, and the corresponding products $\mathbf{C}$ and $\mathbf{K}$ were prepared. The products were hydrolyzed using $\mathrm{K}_{2} \mathrm{CO}_{3}$ as a base to yield the product $\mathbf{D}$ and $\mathbf{L}$ [26-30]. In the presence of 3-(ethyliminomethylideneamino)- $N, N$-dimethylpropane-1-amine, hydrochloride (EDCI), the aromatic oxyacetic acid reacted with substituted 1,3-cyclohexanediones or substituted 1,3-dimethyl$1 H$-pyrazole-5-ol, using DMAP as the catalyst. Subsequently, the key enol ester $\mathbf{E}$ and $\mathbf{M}$ were respectively obtained. Finally, Fries-type rearrangements were performed in anhydrous DCM at room temperature to afford the title compounds I and III [31].

As shown in Scheme 4, the title compounds II were obtained by a five-step synthetic route using the commercially available 2,3,5,6-tetrachloropyridine as the starting material. In the presence of TBAB, the starting material was hydrolyzed using $\mathrm{NaOH}$ in water at $100{ }^{\circ} \mathrm{C}$. The resulting solution was cooled and hydrolyzed with $\mathrm{HCl}$ solution that yielded compound $\mathbf{F}$. Subsequent preparations for compounds $\mathbf{G}, \mathbf{H}, \mathbf{J}$ and II were respectively the same as for compounds $\mathbf{C}, \mathbf{D}, \mathbf{E}$ and $\mathbf{I}$.

All intermediates were synthesized and characterized as detailed in Supporting Information File 1. The structures of all prepared compounds were confirmed by ${ }^{1} \mathrm{H}$ and ${ }^{13} \mathrm{C}$ NMR spectroscopy, and HRMS. Furthermore, the structures of compounds I18 and III4 were verified by X-ray diffractometry (Figure 3). Crystallographic data for crystalline I18 and III4 have been deposited with the Cambridge Crystallographic Data Centre (CCDC 1959130, CCDC 1959152).

\section{HPPD inhibition}

The title compounds displayed promising AtHPPD inhibitory activities, with Table 1 and Table 2 revealing that compounds $\mathbf{I 1 2}\left(K_{\mathrm{i}}=0.011 \mu \mathrm{M}\right)$ and $\mathbf{I 2 3}\left(K_{\mathrm{i}}=0.012 \mu \mathrm{M}\right)$ exhibit similar inhibitor potencies to that of mesotrione $\left(K_{\mathrm{i}}=0.013 \mu \mathrm{M}\right)$. Docking studies using the CDOCKER module within Discovery Studio 4.0 revealed the bioactive binding site positions of potential inhibitors within the targets active site. We modeled the interactions of I12 and II4 (C) with AtHPPD (PDB ID: 1TFZ). The structure of AtHPPD was taken from the PDB data bank. All molecular modeling studies were carried out as previously reported $[10,19,32-34]$. The results show that two main interactions exist between $\mathbf{I 1 2}$ and the AtHPPD

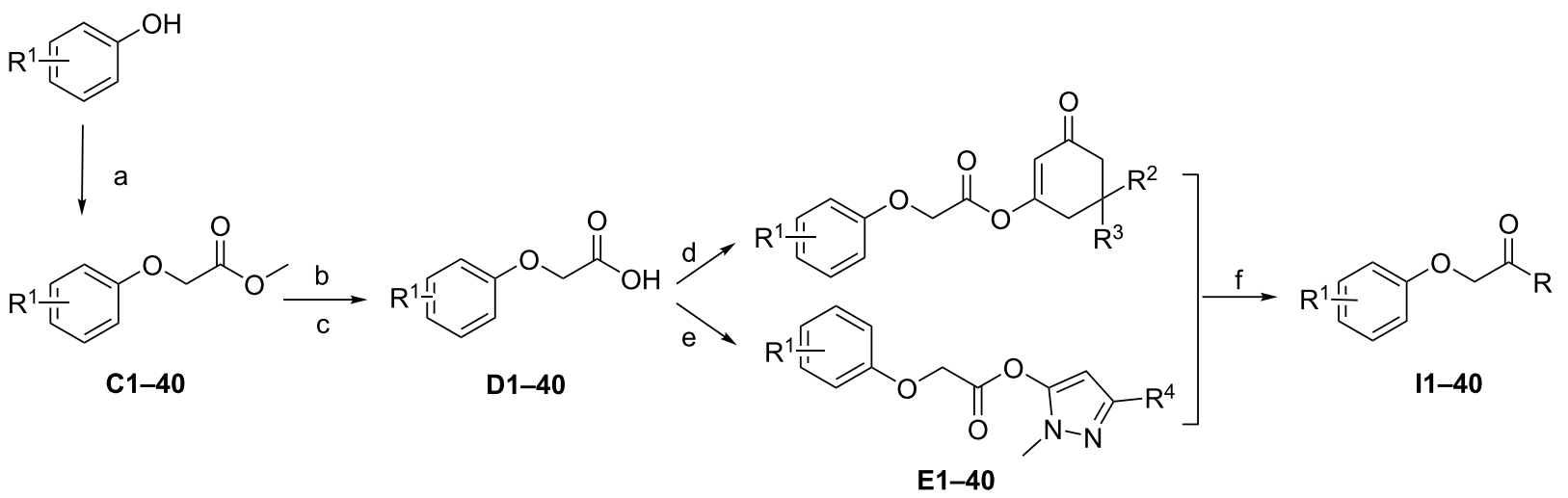<smiles>[R]=CC1=C(O)CCCC1=O</smiles><smiles>CCc1c(C)nn(C)c1O</smiles><smiles>Cc1c(C(F)(F)F)nn(C)c1O</smiles><smiles>Cc1c(C2CC2)nn(C)c1O</smiles>

Scheme 2: Synthetic route of the title compounds I. Reagents and conditions: (a) methyl chloroacetate, $\mathrm{K}_{2} \mathrm{CO}_{3}, \mathrm{CH}_{3} \mathrm{CN}, 65{ }^{\circ} \mathrm{C}$; (b) $\mathrm{K}_{2} \mathrm{CO}_{3}, \mathrm{H}_{2} \mathrm{O}$, $65^{\circ} \mathrm{C}$; (c) aqueous $\mathrm{HCl}$ solution (10\%), rt; (d) substituted 1,3-cyclohexanediones, EDCI, DMAP, DCM, rt; (e) substituted 1,3-dimethyl-1H-pyrazol-5-ol, $\mathrm{EDCl}$, DMAP, DCM, rt; (f) Et $3 \mathrm{~N}$, acetone cyanohydrin, DCM, rt. 


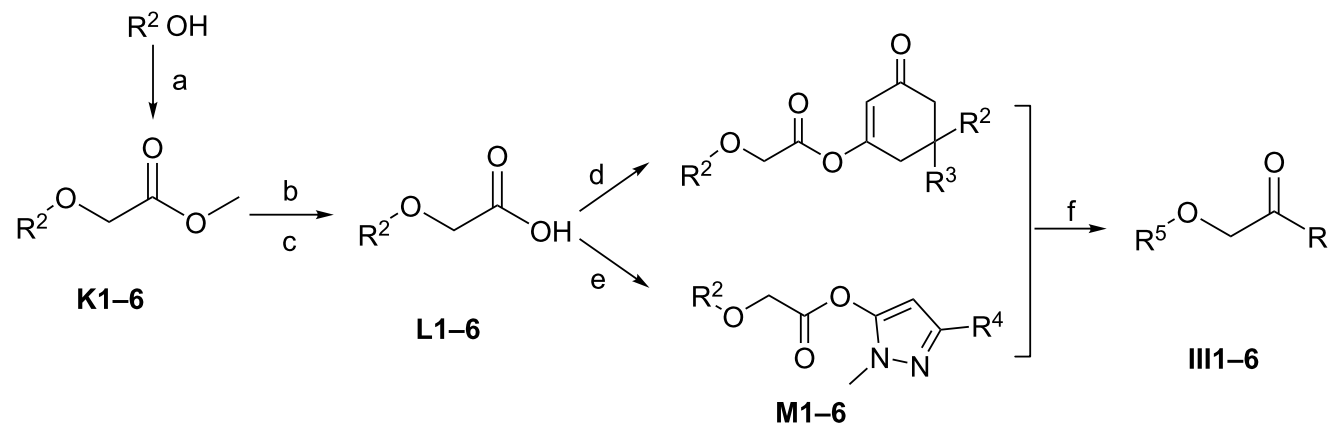<smiles>[R]=CI1C(=O)CCCC1=O</smiles><smiles>CC1=C(O)CC(C)(C)CC1=O</smiles><smiles>Cc1nn(C)c(O)c1I</smiles><smiles>Cc1c(C(F)(F)F)nn(C)c1O</smiles><smiles>Cc1c(C2CC2)nn(C)c1O</smiles>

$\mathrm{R}^{5}=$<smiles>CCc1ccc2ccccc2c1I</smiles><smiles>O=[N+]([O-])c1ncccc1I</smiles>

Scheme 3: Synthetic route of the title compound III. Reagents and conditions: (a) methyl chloroacetate, $\mathrm{K}_{2} \mathrm{CO}_{3}, \mathrm{CH}_{3} \mathrm{CN}, 65{ }^{\circ} \mathrm{C} ;(\mathrm{b}) \mathrm{K}_{2} \mathrm{CO}_{3}, \mathrm{H}_{2} \mathrm{O}$, $65^{\circ} \mathrm{C}$; (c) aqueous $\mathrm{HCl}$ solution (10\%), rt; (d) substituted 1,3-cyclohexanediones, EDCl, DMAP, DCM, rt; (e) substituted 1,3-dimethyl-1H-pyrazol-5-ol, EDCI, DMAP, DCM, rt; (f) Et ${ }_{3} \mathrm{~N}$, acetone cyanohydrin, DCM, rt.<smiles>Cc1cc(Cl)c(Cl)nc1Cl</smiles><smiles>Oc1nc(Cl)c(Cl)cc1Cl</smiles>

$\mathbf{F}$<smiles>COC(=O)COc1nc(Cl)c(Cl)cc1Cl</smiles>

G<smiles>O=C(O)COc1nc(Cl)c(Cl)cc1Cl</smiles>

H<smiles>[R]c1cc(OC(=O)COc2nc(Cl)c(Cl)cc2Cl)n(C)n1</smiles><smiles>[R]C(=O)COc1nc(Cl)c(Cl)cc1Cl</smiles>

II1-5
$\mathrm{R}=$<smiles>O=C1CCCC(O)=C1I</smiles><smiles>CCC1=C(O)CC(C)(C)CC1=O</smiles><smiles>Cc1nn(C)c(O)c1C</smiles><smiles>CCc1c(C(F)(F)F)nn(C)c1O</smiles><smiles>Cc1c(C2CC2)nn(C)c1O</smiles>

Scheme 4: Synthetic route of the title compounds II. Reagents and conditions: (a) $\mathrm{NaOH}, \mathrm{TBAB}, \mathrm{H}_{2} \mathrm{O}, 100{ }^{\circ} \mathrm{C}$; (b) concentrated $\mathrm{HCl}$ solution, rt; (c) methyl chloroacetate, $\mathrm{K}_{2} \mathrm{CO}_{3}, \mathrm{CH}_{3} \mathrm{CN}, 65^{\circ} \mathrm{C}$; (d) $\mathrm{K}_{2} \mathrm{CO}_{3}, \mathrm{H}_{2} \mathrm{O}, 65^{\circ} \mathrm{C}$; (e) aqueous $\mathrm{HCl}$ solution (10\%), rt; (f) substituted 1,3-cyclohexanediones, EDCI, DMAP, DCM, rt; (g) substituted 1,3-dimethyl-1H-pyrazol-5-ol, EDCI, DMAP, DCM, rt; (h) Et 3 N, acetone cyanohydrin, DCM, rt. 


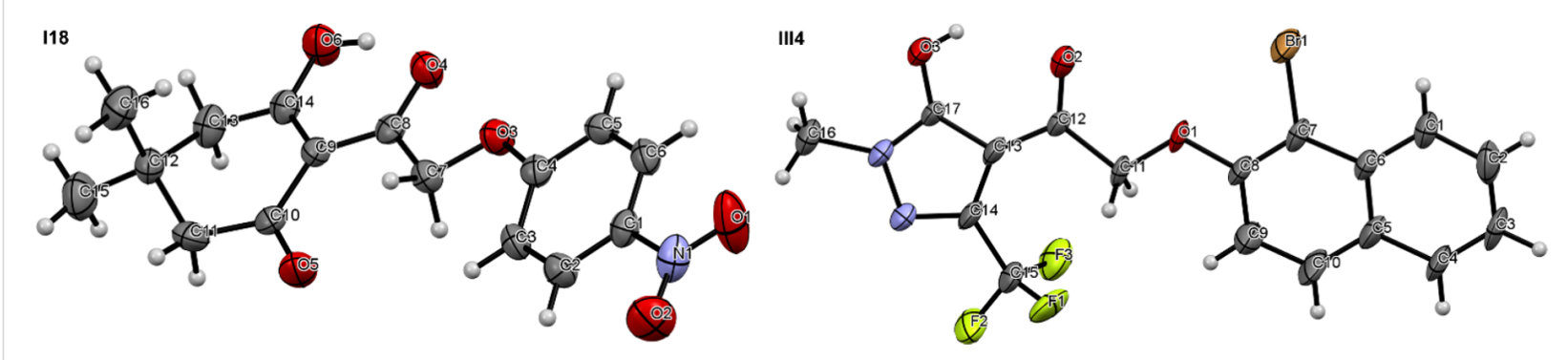

Figure 3: Crystal structures of I18 and III4.

Table 1: Chemical structures of title compound I and their biological activity against AtHPPD.

$$
\overbrace{11-40}^{2} \overbrace{R}^{2}
$$

compound

$\mathrm{R}^{1}$

$\mathrm{R}$

AtHPPD inhibition $K_{\mathrm{i}}(\mu \mathrm{M})$

11

$\mathrm{H}$<smiles>Cc1c(C2CC2)nn(C)c1O</smiles>

$1.5 \pm 0.031$

12

H

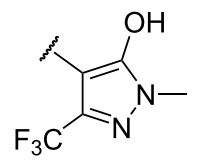

$1.3 \pm 0.017$

13

2-chloro

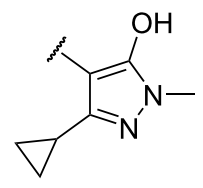

$0.36 \pm 0.012$

14

2-chloro

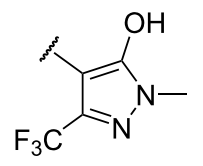

$0.59 \pm 0.043$

15

4-chloro<smiles>CC1=C(O)CC(C)(C)CC1=O</smiles>

$1.0 \pm 0.036$

16

4-chloro

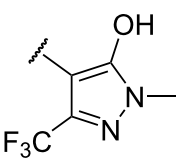

$0.93 \pm 0.032$

17

2,4-dichloro 
Table 1: Chemical structures of title compound I and their biological activity against AtHPPD. (continued)

18

2,4-dichloro

19

2,4,6-trichloro

I10

I11

I12

I13

I14

I15

I16

2-nitro

117

119<smiles>Cc1c(C(F)(F)F)nn(C)c1O</smiles><smiles>CC1(C)CC(=O)C(I)=C(O)C1</smiles><smiles>Cc1nn(C)c(O)c1I</smiles>

$0.24 \pm 0.003$<smiles>Cc1c(C2CC2)nn(C)c1O</smiles>

$0.081 \pm 0.001$<smiles>Cn1nc(C(F)(F)F)c(I)c1O</smiles>

$0.011 \pm 0.012$<smiles>CC1(C)CC(=O)C(I)=C(O)C1</smiles>

$0.45 \pm 0.033$<smiles>Cc1nn(C)c(O)c1C</smiles>

$0.21 \pm 0.042$<smiles>Cc1c(C2CC2)nn(C)c1O</smiles>

$0.27 \pm 0.004$<smiles>Cn1nc(C(F)(F)F)c(I)c1O</smiles>

$0.44 \pm 0.013$<smiles>O=C1CCCC(O)=C1I</smiles>

$0.23 \pm 0.004$<smiles>CC1(C)CC(=O)C(I)=C(O)C1</smiles>

$0.93 \pm 0.006$<smiles>Cc1nn(C)c(O)c1I</smiles>

$0.63 \pm 0.002$ 
Table 1: Chemical structures of title compound I and their biological activity against AtHPPD. (continued)

120

4-nitro

121

4-nitro

122

2-chloro-4-nitro

123

2-chloro-4-nitro

125

2-chloro-4-nitro

126

2-(2,4-dichlorophenoxy)-4-chloro

127

2-(2,4-dichlorophenoxy)-4-chloro

128

2-(2,4-dichlorophenoxy)-4-chloro

129 2-(2,4-dichlorophenoxy)-4-chloro

130

2,4-dimethyl

I31

2,4-dimethyl

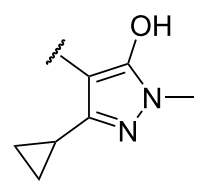

$0.50 \pm 0.003$<smiles>Cc1c(C(F)(F)F)nn(C)c1O</smiles>

$1.5 \pm 0.041$<smiles>CC1(C)CC(=O)C(I)=C(O)C1</smiles>

$1.02 \pm 0.009$<smiles>Cc1nn(C)c(O)c1C</smiles>

$0.012 \pm 0.009$<smiles>Cc1c(C2CC2)nn(C)c1O</smiles>

$0.26 \pm 0.012$<smiles>Cn1nc(C(F)(F)F)c(I)c1O</smiles>

$0.21 \pm 0.043$<smiles>CC1=C(O)CCCC1=O</smiles>

$1.9 \pm 0.001$<smiles>CC1(C)CC(=O)C(I)=C(O)C1</smiles>

$2.2 \pm 0.041$<smiles>Cc1nn(C)c(O)c1I</smiles>

$0.032 \pm 0.002$<smiles>Cc1c(C2CC2)nn(C)c1O</smiles>

$1.3 \pm 0.022$<smiles>O=C1CCCC(O)=C1I</smiles>

$2.2 \pm 0.034$<smiles>CC1(C)CC(=O)C(I)=C(O)C1</smiles> 
Table 1: Chemical structures of title compound I and their biological activity against AtHPPD. (continued)

132

2,4-dmethyl

133

I34

135

4-methyl-5-methoxy

136

137

4-methyl-5-methoxy

138

4-methyl-5-methoxy

139

$\mathrm{H}$

140

$\mathrm{H}$

mesotrione

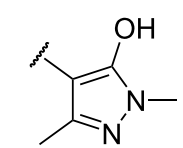

$2.0 \pm 0.009$

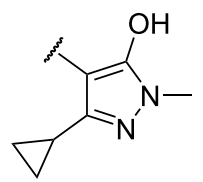

$2.8 \pm 0.045$

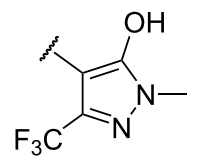

$2.8 \pm 0.67$

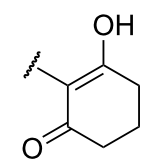

$3.3 \pm 0.14$

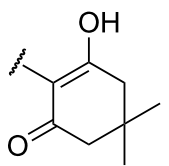

$3.4 \pm 0.21$

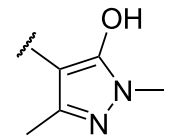

$2.7 \pm 0.53$

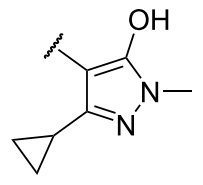

$2.9 \pm 0.038$

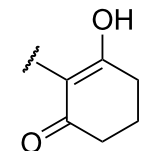

$1.3 \pm 0.056$

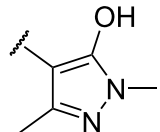

$1.2 \pm 0.031$

$0.013 \pm 0.001$

Table 2: Chemical structures of title compound II, III and their biological activity against AtHPPD.

$$
\mathrm{R}_{\mathrm{I1} 1-5, \mathrm{II1}-6}^{\mathrm{O}}
$$

compound

$\mathrm{R}^{5}$

$\mathrm{R}$<smiles>O=C1CCCC(O)=C1I</smiles>

II1

2,3,5-trichloro-6-pyridyl
AtHPPD inhibition

$K_{\mathrm{i}}(\mu \mathrm{M})$ 
Table 2: Chemical structures of title compound II, III and their biological activity against AtHPPD. (continued)

112

2,3,5-trichloro-6-pyridyl

II3

2,3,5-trichloro-6-pyridyl

114

2,3,5-trichloro-6-pyridyl

II5

2,3,5-trichloro-6-pyridyl

III1

2-bromo-2-naphthyl

III2

2-bromo-2-naphthyl

III3

2-bromo-2-naphthyl

III4

2-bromo-2-naphthyl

III5

2-nitro-3-pyridyl

III6

2-nitro-3-pyridyl<smiles>CC1=C(O)C(=O)CC(C)(C)C1</smiles>

$0.097 \pm 0.010$<smiles>Cc1nn(C)c(O)c1C</smiles>

$0.021 \pm 0.004$<smiles>Cc1c(C2CC2)nn(C)c1O</smiles>

$0.023 \pm 0.006$<smiles>Cc1c(C(F)(F)F)nn(C)c1O</smiles>

$0.12 \pm 0.003$<smiles>CC1=C(O)CC(C)(C)CC1=O</smiles>

$2.50 \pm 0.011$<smiles>Cc1nn(C)c(O)c1C</smiles>

$2.2 \pm 0.090$

$2.2 \pm 0.13$<smiles>Cc1c(C2CC2)nn(C)c1O</smiles><smiles>Cc1c(C(F)(F)F)nn(C)c1O</smiles><smiles>CC1=C(O)CCCC1=O</smiles>

$0.23 \pm 0.011$<smiles>Cc1c(C2CC2)nn(C)c1O</smiles>

active site (Figure 4), as was observed for mesotrione; the 1,3-dicarbonyl unit is chelated to the iron ion, and the aromatic ring moiety formed $\pi-\pi$ interactions with Phe403 and Phe360.

Electron-withdrawing and electron-donating groups were introduced onto the benzene ring of I1, which significantly influenced the HPPD inhibition activity. We found that electron-withdrawing groups improve the activity; for example, I3 $\left(K_{\mathrm{i}}=0.36 \mu \mathrm{M}\right)$ and $\mathbf{I} \mathbf{4}\left(K_{\mathrm{i}}=0.59 \mu \mathrm{M}\right)$ were more potent than $\mathbf{I 1}$ $\left(K_{\mathrm{i}}=1.5 \mu \mathrm{M}\right)$ and $\mathbf{I} 2\left(K_{\mathrm{i}}=1.3 \mu \mathrm{M}\right)$. In addition, the position of the electron-withdrawing group played an essential role in determining the HPPD inhibitory activity. In most cases, compounds with a chlorine atom at the 2-position (I4) were 

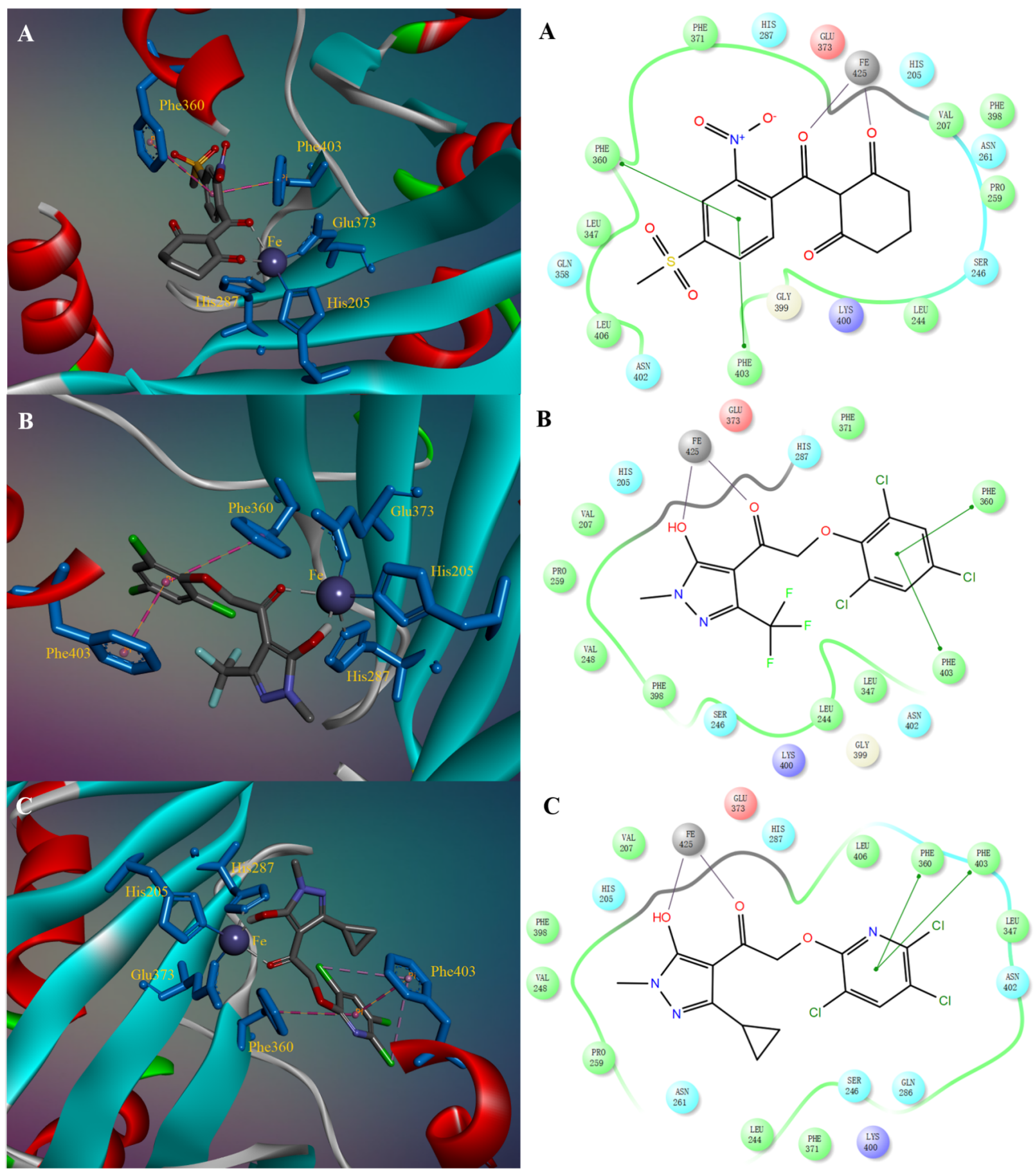

Figure 4: Simulated binding mode of mesotrione (A), compound I12 (B) and compound II4 (C) with AtHPPD. The key residues in the active site are shown in blue sticks, and Fe ${ }^{I I}$ is shown as a dark blue sphere. mesotrione, compound I12, and II4 are shown in gray sticks.

more active than those with the chlorine at the 4-position (I6), clearly an electron-withdrawing group at the 2-position provides enhanced activity compared to the 4-position. In addition, electron-donating groups were found to be detrimental to HPPD inhibition activity $(\mathbf{I} \mathbf{>} \mathbf{I 3 3}, \mathbf{I 3 8})$. We observed that methyl groups at the 5-position of the 1,3-cyclohexane ring were unfavorable to activity $(\mathbf{I 1 7}>$ I18, I26 $>$ I27, II1 $>$ II2), and that the introduction a nitro group led to more potent activity compared to that generated by a chlorine atom (except for I6 and I21), such that I15 $>$ I3, I18 $>$ I5, and I24 $>$ I7 in terms of activity. Generally speaking, compounds with a pyrazole ring exhibited better HPPD inhibitory activities than 
those with cyclohexanedione rings $(\mathbf{I 2 8}, \mathbf{I 2 9}>\mathbf{I 2 6}, \mathbf{I 2 7}$; II3, II4 > II1, II2).

\section{Herbicidal activity}

The post-emergence herbicidal activities of the title compounds are summarized in Figure 5. In our work, these weeds, E. crusgalli (EC), S. faberii (SF), D. sanguinalis (DS), A. retroflexus (AR), E. prostrata (EP), and A. juncea (AJ), were selected for evaluating the post-emergence herbicidal activities of the title compounds.

Some of the synthesized compounds exhibited better control efficiencies for the test weed; among them, compounds $\mathbf{I 2 8}$, I29, II3 and II4 showed broad-spectrum herbicidal activities, with II4 even showing a slightly higher herbicidal activity than mesotrione at a rate of $150 \mathrm{~g}$ ai/ha. When the structure of compound II4 was superimposed onto that of mesotrione, the posi- tive control drug, we observed that it perfectly fits into the active pocket, as shown in Figure 6.

In this work, two categories of HPPD inhibitors were synthesized, including triketone and pyrazole derivatives. Compared with the triketone derivatives, the pyrazole-containing derivatives were generally more herbicidally potent. For instance, pyrazole-containing compounds I11 and I12 displayed enhanced activities relative to compound $\mathbf{I 9}$, which contains a cyclohexanedione ring. We also observed that the introduction of methyl groups at the 5-position of the 1,3-cyclohexane ring was detrimental to herbicidal activity $($ I17 $>$ I18, I26 $>$ I27, II1 > II2). Compounds with electron-withdrawing groups on the aromatic ring were found to displayed higher herbicidal activities than those with electron-donating groups (i.e., I7 > I33, I8 $>$ I34), which is consistent with the observed $A t$ HPPD inhibitory activity, and $\mathbf{I} 28$ and $\mathbf{I 2 9}$ had significantly superior

Sum of Inhibition Rate of Compounds I1-126

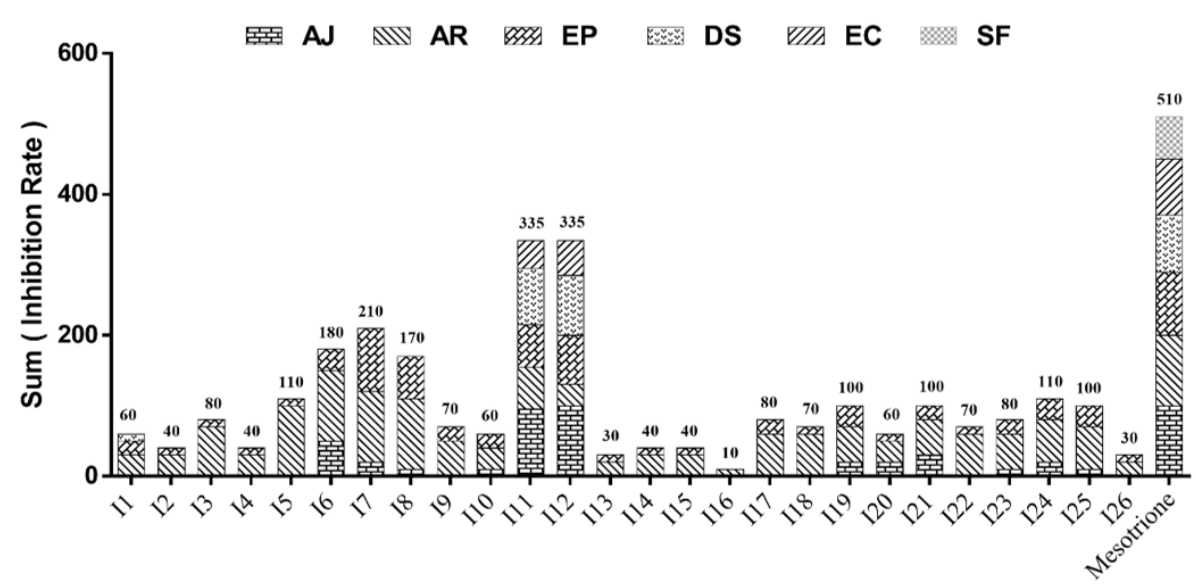

Sum of Inhibition Rate of Compounds I27-III6

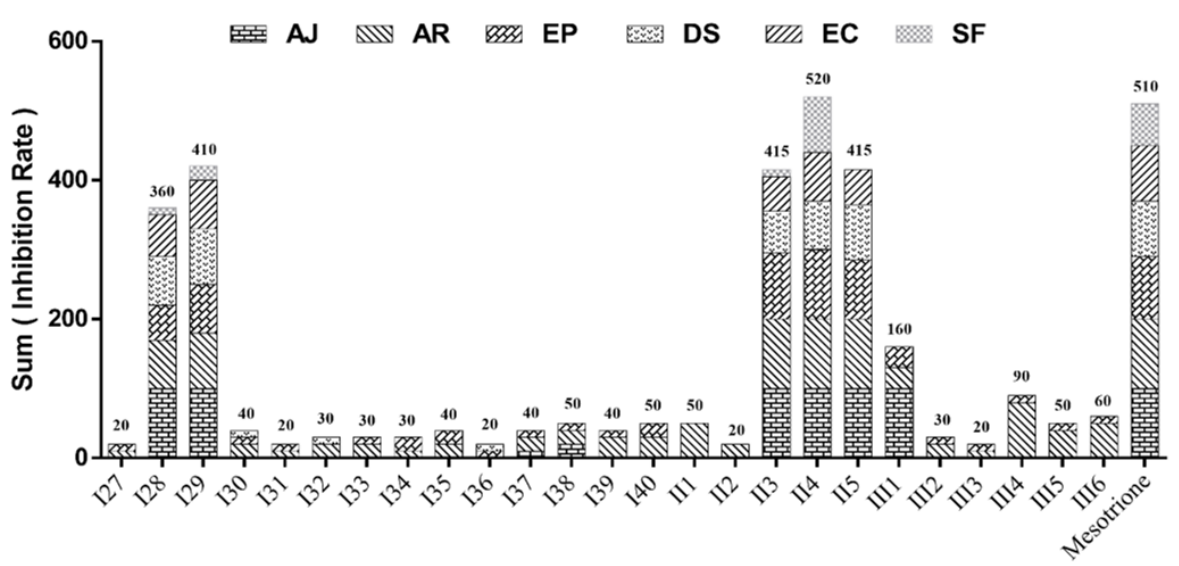

Figure 5: Sum of inhibition rate of title compounds at $150 \mathrm{~g}$ ai/ha. (Abbreviations: AJ, Abutilon juncea; AR, Amaranthus retroflexus; EP, Eclipta prostrata; DS, Digitaria sanguinalis; EC, Echinochloa crus-galli; SF, Setaria faberii.) 


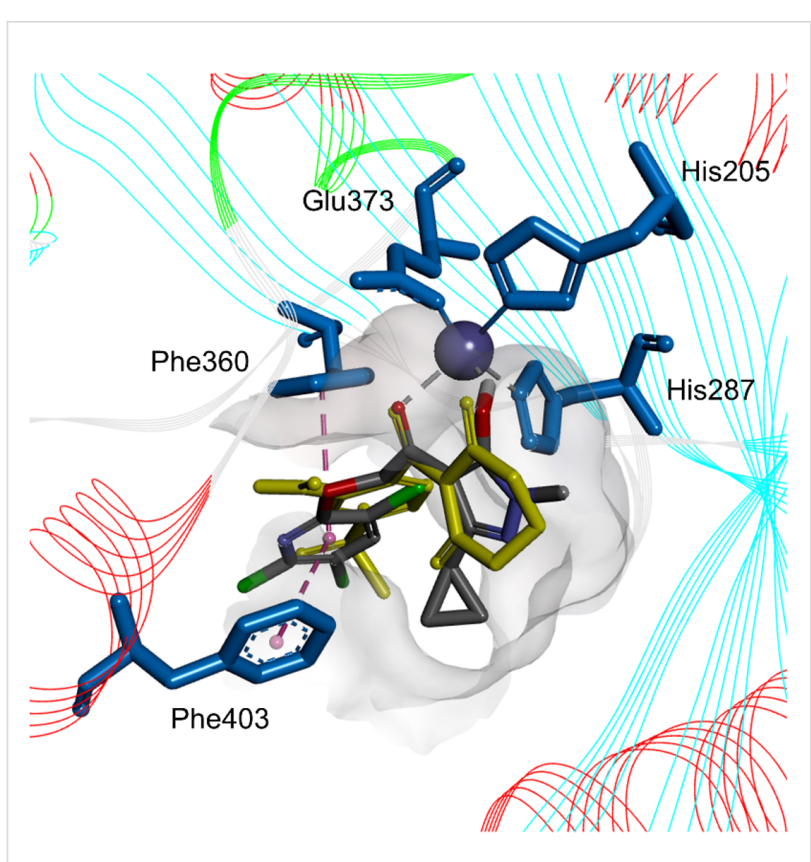

Figure 6: Simulated folding mode of mesotrione (yellow sticks) and compound II4 (gray sticks) with AtHPPD. The key residues in the active site are shown in blue sticks, and Fe" is shown as a dark blue sphere.

herbicidal activities. Thus, the introduction of large groups on the benzene ring appears to be beneficial to the activity and deserves further structural optimization.

The herbicidal activities of compounds containing other aromatic rings, compound II and III bearing a pyridine ring and a naphthalene ring, were examined. The results show that the chloro-substituted pyridine exhibited superior herbicidal activity, which provides a theoretical basis for the further development of highly effective HPPD herbicides. Some compounds with significant AtHPPD inhibitory activities were found not to exhibit promising herbicidal activities. For example, compound I12, with the best $A t$ HPPD inhibition activity $\left(K_{\mathrm{i}}=0.011 \mu \mathrm{M}\right)$ exhibited poorer than expected herbicidal activity, which is possibly related to its stability and metabolism in the plant [2].

\section{Crop safety}

Crop safety is one of the main considerations during herbicide discovery. Compound II3, II4, and II5, which exhibited excellent herbicidal activities, were chosen for further crop safety studies and to evaluate whether or not they have the potential to be developed as herbicides (Table 3). Commercial mesotrione was selected as the positive control HPPD herbicide. We found that wheat and maize showed high tolerance to compound II3 at a dosage of $150 \mathrm{~g}$ ai/ha, however, its herbicidal activity could not compete with that of mesotrione. In addition, maize displayed tolerance to compound II4, indicating that II4 had the potential to be developed as a postemergence herbicide for weed control in maize fields.

\section{Conclusion}

A series of aryloxyacetic acid derivates was synthesized as novel HPPD inhibitors. The bioassay studies revealed that some of the title compounds, such as compound $\mathbf{I 1 2}\left(K_{\mathrm{i}}=0.011 \mu \mathrm{M}\right)$, $\mathbf{I 2 3}\left(K_{\mathrm{i}}=0.012 \mu \mathrm{M}\right)$, showed similar AtHPPD inhibitor potencies to that of mesotrione $\left(K_{\mathrm{i}}=0.013 \mu \mathrm{M}\right)$. Moreover, several newly synthesized compounds displayed strong, broad spectrum weed control when dosed at $150 \mathrm{~g}$ ai/ha. Most importantly, compound II4, with good HPPD inhibition activity $\left(K_{\mathrm{i}}=0.023 \mu \mathrm{M}\right)$, exhibited a slightly higher herbicidal activity than mesotrione. In addition, II4 was found to be safe for use on maize. These results suggest that compound II4 is a promising HPPD inhibiting herbicide candidate deserving of further optimization studies.

\section{Experimental}

The experimental details and analytical data for intermediates $\mathbf{C}$ to $\mathbf{M}$ and title compounds were given in Supporting Information File 1. The chemical structures of all title compounds were confirmed by ${ }^{1} \mathrm{H}$ and ${ }^{13} \mathrm{C}$ NMR spectroscopic analyses and HRMS spectrometric analyses.

\section{X-ray diffraction}

Single crystals of compounds I18 and III4 were cultivated for structure validation. Compound $\mathbf{I 1 8}$ was recrystallized from a

Table 3: Postemergence crop safety of compounds II3, II4 and II5 (150 g ai/ha).

compound

\begin{tabular}{cc} 
& \\
\hline II3 & 150 \\
II4 & 150 \\
II5 & 150 \\
mesotrione & 150
\end{tabular}


mixture of DCM/methanol to afford a colorless transparent crystal. It crystallized in the monoclinic space group: P-1 (2), cell: $a=6.425(4) \AA, b=9.854(6) \AA, c=13.205(8) \AA$, $\alpha=93.974(7)^{\circ}, \beta=102.211(7)^{\circ}, \gamma=107.567(7)^{\circ}$, temperature: 298 K. Compound III4 was recrystallized from a mixture of $\mathrm{DCM} /$ methanol to afford a colorless transparent crystal. It crystallized in the monoclinic space group: $\mathrm{P}-1$ (2), cell: $a=5.191(5) \AA, b=12.133(12) \AA, c=13.576(14) \AA$, $\alpha=80.141(13)^{\circ}, \beta=81.978(12)^{\circ}, \gamma=79.496(12)^{\circ}$, temperature: 296 K. X-ray crystal structure of compound I18 and III4 are shown in Figure 3.

Crystallographic data for crystal compounds I18 and III4 were deposited with the Cambridge Crystallographic Data Centre as supplementary publications with the deposition numbers CCDC 1959130 and CCDC 1959152, respectively. The data can be obtained free of charge from http://www.ccdc.cam.ac.uk/.

\section{Docking study}

The docking study was conducted with the method reported previously [10,19,32-34]. Crystal structures of Arabidopsis thaliana HPPD (PDB ID: 1TFZ) with the native ligand, named DAS869 were downloaded from the Protein Data Bank. The docking was carried out using Discovery Studio 4.0. During the docking process, all water molecules were removed. The ligand and protein were prepared with the Dock Ligands tool before docking. By using Define and Edit Binding Site tool to identify the active site. Then the center of the native ligand was deleted. Utilizing the CDOCKER, the prepared ligand was docked into the protein receptor binding site. After the docking calculations were performed, the best binding modes were determined by docking scores and also compared with the simulated binding mode of mesotrione with AtHPPD.

\section{Enzyme inhibition study}

$A t$ HPPD was prepared and purified according to the reported methods in the literature [19,20,35-37]. The inhibition constant $\left(K_{\mathrm{i}}\right)$ was obtained and shown in Table 1 and Table 2.

\section{Herbicidal activities}

The post-emergence herbicidal activities of the title compounds were evaluated against monocotyledon weeds (E. crus-galli, $S$. faberii, and D. sanguinalis) and broadleaf weeds (A. retroflexus, E. prostrata, and A. juncea) in the greenhouse experiments. The commercial HPPD herbicide mesotrione was regarded as a control. All tested compounds were dissolved in DMF as $100 \mathrm{~g} / \mathrm{L}$ emulsified concentrates, containing $1 \%$ Tween-80 as emulsifier. Then the solvent was diluted with distilled water. Flowerpots with an inner diameter of $7.5 \mathrm{~cm}$ were filled with complex nutrient soil to three-fourths of their height. The above six weed targets were respectively grown in the pots and covered with soil to a thickness of $0.2 \mathrm{~cm}$ and grown in the greenhouse. When the weeds grew to about the three-leaf stage, they were treated by the title compounds at the rate of $150 \mathrm{~g}$ ai/ha. After 18 days of treatment with inhibitors, the herbicidal activities were surveyed and evaluated with two duplicates per experiment [19]. (Figure 5)

\section{Crop selectivity}

The representative crops, rice, wheat, maize, cotton, soybean, and canola were selected to test the crop safety of compound II3, II4, and II5. The six crops were separately planted in flowerpots (12 cm diameter) containing the composite nutrient soil and grown at room temperature. When the crops had reached the four-leaf stage, the safety experiments were conducted at the rate of $150 \mathrm{~g}$ ai/ha. After 15 days, the final results of crop safety were evaluated with two duplicates per experiment (Table 3).

\section{Supporting Information}

\section{Supporting Information File 1}

Additional experimental and analytical data, and NMR

spectra of synthesized compounds.

[https://www.beilstein-journals.org/bjoc/content/

supplementary/1860-5397-16-25-S1.pdf]

\section{Acknowledgments}

The author thanks Prof. Da-Yong Zhang and Hao Huang for experimental guidance, Zhejiang University Chemical Industry Research Institute for biological activity assay, and National Natural science Foundation of China (30973607, 81172934), "Double First-Class" New Drug Development Project of China Pharmaceutical University (CPU2018PZQ15) for financial supports

\section{ORCID ${ }^{\circledR}$ iDs}

Man-Man Wang - https://orcid.org/0000-0003-1038-1559

\section{Preprint}

A non-peer-reviewed version of this article has been previously published as a preprint doi:10.3762/bxiv.2019.150.v1

\section{References}

1. Yang, C.; Pflugrath, J. W.; Camper, D. L.; Foster, M. L.; Pernich, D. J.; Walsh, T. A. Biochemistry 2004, 43, 10414-10423. doi:10.1021/bi049323o

2. He, B.; Wang, D.; Yang, W.; Chen, Q.; Yang, G. Chin. J. Org. Chem. 2017, 37, 2895. doi:10.6023/cjoc201705031

3. Riggins, C. W.; Peng, Y.; Stewart, C. N., Jr.; Tranel, P. J. Pest Manage. Sci. 2010, 66, 1042-1052. doi:10.1002/ps.2006 
4. Wójcik, A.; Broclawik, E.; Siegbahn, P. E. M.; Lundberg, M.; Moran, G.; Borowski, T. J. Am. Chem. Soc. 2014, 136, 14472-14485. doi:10.1021/ja506378u

5. Lee, D. L.; Knudsen, C. G.; Michaely, W. J.; Chin, H.-L.; Nguyen, N. H.; Carter, C. G.; Cromartie, T. H.; Lake, B. H.; Shribbs, J. M.; Fraser, T. Pestic. Sci. 1998, 54, 377-384. doi:10.1002/(sici)1096-9063(199812)54:4<377::aid-ps827>3.0.co;2-0

6. Diebold, A. R.; Brown-Marshall, C. D.; Neidig, M. L.; Brownlee, J. M.; Moran, G. R.; Solomon, E. I. J. Am. Chem. Soc. 2011, 133, 18148-18160. doi:10.1021/ja202549q

7. Hall, M. G.; Wilks, M. F.; Provan, W. M.; Eksborg, S.; Lumholtz, B. Br. J. Clin. Pharmacol. 2001, 52, 169-177. doi:10.1046/j.0306-5251.2001.01421.x

8. Lewis, R. W.; Botham, J. W. Crit. Rev. Toxicol. 2013, 43, 185-199. doi:10.3109/10408444.2013.764279

9. Hawkes, T. R.; Langford, M. P.; Viner, R.; Blain, R. E.; Callaghan, F. M.; Mackay, E. A.; Hogg, B. V.; Singh, S.; Dale, R. P. Pestic. Biochem. Physiol. 2019, 156, 9-28. doi:10.1016/j.pestbp.2019.01.006

10. Li, H.-B.; Li, L.; Li, J.-X.; Han, T.-F.; He, J.-L.; Zhu, Y.-Q. Pest Manage. Sci. 2018, 74, 579-589. doi:10.1002/ps.4739

11. Neidig, M. L.; Decker, A.; Choroba, O. W.; Huang, F.; Kavana, M.; Moran, G. R.; Spencer, J. B.; Solomon, E. I.

Proc. Natl. Acad. Sci. U. S. A. 2006, 103, 12966-12973. doi:10.1073/pnas.0605067103

12. Borowski, T.; Bassan, A.; Siegbahn, P. E. M. Biochemistry 2004, 43, 12331-12342. doi:10.1021/bi049503y

13. Ahrens, H.; Lange, G.; Müller, T.; Rosinger, C.; Willms, L.; van Almsick, A. Angew. Chem., Int. Ed. 2013, 52, 9388-9398. doi:10.1002/anie.201302365

14. Heap, I. International survey of herbicide resistant weeds. http://www.weedscience.com.

15. Beaudegnies, R.; Edmunds, A. J. F.; Fraser, T. E. M.; Hall, R. G.; Hawkes, T. R.; Mitchell, G.; Schaetzer, J.; Wendeborn, S.; Wibley, J. Bioorg. Med. Chem. 2009, 17, 4134-4152. doi:10.1016/j.bmc.2009.03.015

16. Zhu, Y. Q.; Hu, F. Z.; Yang, H. Z. Huaxue Tongbao 2004, 67, w018/1-w018/7.

17. Freitas, L. M.; de Assis Valadares, L. P.; Camozzi, M. G. M.; de Oliveira, P. G.; Ferreira Machado, M. R.; Lima, F. C. Hum. Exp. Toxicol. 2019, 38, 1178-1182. doi:10.1177/0960327119860172

18. Ndikuryayo, F.; Kang, W.-M.; Wu, F.-X.; Yang, W.-C.; Yang, G.-F. Eur. J. Med. Chem. 2019, 166, 22-31. doi:10.1016/j.ejmech.2019.01.032

19. Fu, Y.; Zhang, S.-Q.; Liu, Y.-X.; Wang, J.-Y.; Gao, S.; Zhao, L.-X.; Ye, F. Ind. Crops Prod. 2019, 137, 566-575. doi:10.1016/j.indcrop.2019.05.070

20. Wang, D.-W.; Lin, H.-Y.; Cao, R.-J.; Ming, Z.-Z.; Chen, T.; Hao, G.-F.; Yang, W.-C.; Yang, G.-F. Pest Manage. Sci. 2015, 71, 1122-1132. doi:10.1002/ps.3894

21. Kovacs, P. R.; Patel, K. M.; Selby, T. P.; Smith, B. T.; Taggi, A. E. Herbicidal pyrimidone derivatives. WO Patent WO2011031658 A1, March 17, 2011.

22. Lian, L.; Lu, X.; Wu, J.; Zhang, H. Chin. J. Pestic. Sci. 2020, 22, 1-9.

23. Witschel, M. Bioorg. Med. Chem. 2009, 17, 4221-4229. doi:10.1016/j.bmc.2008.11.006

24. Wang, D.-W.; Lin, H.-Y.; He, B.; Wu, F.-X.; Chen, T.; Chen, Q.; Yang, W.-C.; Yang, G.-F. J. Agric. Food Chem. 2016, 64, 8986-8993. doi:10.1021/acs.jafc.6b04110
25. Jensen, B. S. Acta Chem. Scand. 1959, 13, 1668-1670. doi:10.3891/acta.chem.scand.13-1668

26. He, H.-W.; Yuan, J.-L.; Peng, H.; Chen, T.; Shen, P.; Wan, S.-Q.; Li, Y.; Tan, H.-L.; He, Y.-H.; He, J.-B.; Li, Y. J. Agric. Food Chem. 2011, 59, 4801-4813. doi:10.1021/jf104247w

27. Wang, W.; He, H.-W.; Zuo, N.; He, H.-F.; Peng, H.; Tan, X.-S. J. Agric. Food Chem. 2012, 60, 7581-7587. doi:10.1021/jf301829m

28. He, H.-W.; Peng, H.; Wang, T.; Wang, C.; Yuan, J.-L.; Chen, T.; He, J.; Tan, X. J. Agric. Food Chem. 2013, 61, 2479-2488. doi:10.1021/jf305153h

29. Verma, A. K.; Rustagi, V.; Aggarwal, T.; Singh, A. P. J. Org. Chem. 2010, 75, 7691-7703. doi:10.1021/jo101526b

30. Suzuki, M.; Iwasaki, H.; Fujikawa, Y.; Kitahara, M.; Sakashita, M.; Sakoda, R. Bioorg. Med. Chem. 2001, 9, 2727-2743. doi:10.1016/s0968-0896(01)00198-5

31. Luan, L.-b.; Song, Z.-j.; Li, Z.-m.; Wang, Q.-r. Beilstein J. Org. Chem. 2018, 14, 1826-1833. doi:10.3762/bjoc.14.155

32. Zhu, Y.-q.; Liu, P.; Si, X.-K.; Zou, X.-M.; Liu, B.; Song, H.-B.; Yang, H.-Z. J. Agric. Food Chem. 2006, 54, 7200-7205. doi:10.1021/jf061573j

33. Brownlee, J. M.; Johnson-Winters, K.; Harrison, D. H. T.; Moran, G. R. Biochemistry 2004, 43, 6370-6377. doi:10.1021/bi049317s

34. Schaetzer, J.; Edmunds, A. J. F.; Gaus, K.; Rendine, S.; De Mesmaeker, A.; Rueegg, W. Bioorg. Med. Chem. Lett. 2014, 24 , 4643-4649. doi:10.1016/j.bmcl.2014.08.043

35. Schmidt, S. R.; Muller, C. R.; Kress, W. Eur. J. Biochem. 1995, 228 , 425-430. doi:10.1111/j.1432-1033.1995.00425.x

36. Wang, D.-W.; Lin, H.-Y.; Cao, R.-J.; Chen, T.; Wu, F.-X.; Hao, G.-F.; Chen, Q.; Yang, W.-C.; Yang, G.-F. J. Agric. Food Chem. 2015, 63, 5587-5596. doi:10.1021/acs.jafc.5b01530

37. Lei, K.; Hua, X.-W.; Tao, Y.-Y.; Liu, Y.; Liu, N.; Ma, Y.; Li, Y.-H.; Xu, X.-H.; Kong, C.-H. Bioorg. Med. Chem. 2016, 24, 92-103. doi:10.1016/j.bmc.2015.11.032

\section{License and Terms}

This is an Open Access article under the terms of the

Creative Commons Attribution License

(https://creativecommons.org/licenses/by/4.0). Please note that the reuse, redistribution and reproduction in particular requires that the authors and source are credited.

The license is subject to the Beilstein Journal of Organic Chemistry terms and conditions:

(https://www.beilstein-journals.org/bjoc)

The definitive version of this article is the electronic one which can be found at: doi:10.3762/bjoc. 16.25 